\title{
Anticlastogenic Effects of Tinospora Cordifolia Against Arsenic Induced Genotoxicity Using Micronucleus Assay in Swiss Albino Mice Peripheral Blood Erythrocytes.
}

\author{
Sanjeev Kumar Ambasta ${ }^{1}$, Indrani Trivedi ${ }^{1}$, Seema Kumari ${ }^{2}$, Aniket Kumar ${ }^{3}$, \\ Parmanand Verma ${ }^{1}$, Birendra Prasad ${ }^{1}$, Ranjit Kumar ${ }^{4}$, Upendra Kishor Sinha ${ }^{1}$. \\ ${ }^{I}$ Department of Botany, Faculty of Science, Patna University, Patna, Bihar, India. \\ ${ }^{2}$ Department of Biotechnology, Faculty of Science, Utkal University, Bhubaneswar, Odisha, India. \\ ${ }^{3}$ Department of Biochemistry, Faculty of Science, Patna University, Patna, Bihar, India. \\ ${ }^{4}$ Mahavir Cancer Research Institute, Phulwarishrif, Patna, India
}

\begin{abstract}
The present study was aimed to evaluate anticlastogenic potential of ethanolic extract of T. cordifolia against arsenic induced toxicity. In the course of experiment, thirty animals were taken and divided into five groups each group contains six animals. Group 01 was control fed on distilled water supply while rest four (02, 03, 04, 05) groups were treated with $4 \mathrm{mg} / \mathrm{kg}$ body weight sodium arsenite daily for 8 weeks. After eight weeks sodium arsenite pre-treated groups 04 and 05 were followed by treatment of $80 \mathrm{mg} / \mathrm{kg}$ body weight ethanolic extract of test plant for next 8 weeks. Afterwards blood sample were collected from caudal region of mice without their sacrifice from all groups and smeared on glass slide which was later followed by double staining process. Micronucleus frequency was expressed in the terms of mean and standard deviation. Approximately 2000 cells were scored by help of light microscopy to determine micronucleus frequency. A high index of micronucleus formation in group 02 and 03 due to clastogenic effect of arsenite were observed while its frequency drastically reduced in $T$. cordifolia administered group due to its anticlastogenic effect. Antimutagenic potential of such test plant may be proven as potent herbal drug against genotoxicity. So this herbal extract maybe used as effective drug in preventing genotoxicity.
\end{abstract}

Keywords: Clastogens, spindle apparatus, genotoxic, mitotic delay.

\section{Introduction}

Micronucleus formation is a hallmark of genotoxicity and micronucleus assay is an important component of genotoxicity screening. The formation of micronuclei serves as an index of genetic damages [1]. Micronuclei induction can result from clastogens or aneugens (agent that induces chromosomal loss mainly through interference with spindle apparatus). The major mechanism responsible for micronuclei induction is double stranded DNA breaks. Micronucleus assay may detect clastogens and aneugens including mitotic delay, apoptosis and chromosomal loss or non-disjunction of chromosomes. Micronuclei are chromatin containing bodies that represents fragments or whole chromosome that were not incorporated into the daughter cell nucleus at cell division [2]. The micronucleus is an excellent biomarker because it is able to detect chromosome breakage or ill functions of mitotic spindle caused by aneugenic mechanisms [3]. The micronucleus index in rodents or human cells is one of the standard cytogenetic tests used in the assessment of genetic toxicity in vivo or ex vivo [4]. Micronucleus test not only allows the detection of clastogens as genotoxicants but it also discriminate clastogens from an aneugens [5]. Micronucleus assay is rapid, easy, sensitive method for detection of mutagenicity [6]. Micronucleus test is used for studying anti-mutagenic activity of herbal drug [7]. Those cells are considered micro nucleated in which micronuclei are defined chromatin corpuscles with a diameter less or equal to $1 / 3$ of main cell nucleus and stained equally or lighter than the parent nucleus [8]. In micronucleus test using blood erythrocyte, the blood can be collected for extended period of time and chronic and sub-chronic exposure of clastogens can be evaluated for the same animal in the given conditions [9].

Arsenicals are considered as potent genotoxic and may be proved as carcinogenic based on its physical and chemical forms, concentration and duration of exposure [10]. Arsenic toxicity is related to its ability to combine with proteins and thiol groups of non-protein molecules of cells which causes alteration of cellular pathway [11]. Viability test showed that As (III) is relatively more toxic than As (IV) [12]. Arsenic induced mutagenesis includes the induction of DNA damage and wide varieties of genetic alterations which can ranges from single gene mutation to visible chromosomal mutations. A lots of studies showed that arsenic genotoxicity is mainly related with generation of reactive oxygen species (ROS) during the biotransformation of arsenic compounds inside the living cells, generation of ROS causes DNA strand breaks and chromosomal aberrations [13]. Lots of medicinal herbs and plants are great source of biologically active compounds which may affects the genetic health and general health by maintaining the balance between consumption of mutagenic 
and anti-mutagenic chemicals [14]. T. cordifolia is commonly called as Giloy and it is climbing shrub belongs to family menispermaceae. It is earlier informed that $T$. cordifolia has anti-mutagenic and anti-carcinogenic compounds widely used in Ayurveda [15]. The alcoholic extract of such plant shows the antineoplastic and anti-oxidative properties [16]. It is evident that ethanolic extract of medicinal plants may be useful in preventing deleterious effect of oxidative stress caused by arsenic [17]. In the present study anticlastogenic and antimutagenic effects of $T$. cordifolia stem ethanolic extracts were investigated against arsenic induced toxicity in Swiss albino mice by using the technique micronucleus test in peripheral blood erythrocytes.

\section{Material And Method}

A double staining procedure (Harris hematoxylin and Giemsa stain) was used in this study because double staining method enhances the clarity of micronucleus as well as increases the scoring time [9]. Thirty young and healthy male mice of approximately similar age and weight were caged into five groups and each cage containing six animals. Cages were marked numerically 01, 02, 03, 04, 05. Mice were housed in cage with husk bedding and proper hygienic conditions were maintained throughout the experiment. A balanced diet was provided along with green vegetables and fruits to the experimental animals. The temperature of animal house was kept at $22 \pm 02^{\circ} \mathrm{C}$ with 12 hours alternate light and dark cycle. During the entire experiment, the guidelines of institutional ethical committee were strictly followed. Animals of cage number 02, 03, 04, 05 group of animal were treated with sodium arsenite (Sigma, CAS: 7784-46-5 ) of dose level 4mg/Kg body weight/day for 08 weeks while 01 group animals were behave as control and fed with clean water which was obtained from the tap water supply of Patna city, Bihar (India). Sodium arsenite pre treated groups 04 and 05 were followed by dosing of $80 \mathrm{mg} / \mathrm{kg}$ body weight ethanolic extract of test plant for next 8 weeks (total duration of treatment16 weeks).

\section{Extraction of test plant and dose preparation}

T. cordifolia stem extracts were prepared by dissolving dried grinded powder of plant material in $90 \%$ ethanol and placed on horizontal shaker for 24 hours, then it was subjected to separation of extract by vacuum rotavator (Buchi, R- 3 ) at bath temperature $60^{\circ} \mathrm{C}$, rotation $6 \mathrm{rpm}$ and vacuum pressure was maintained to $310 \mathrm{~m}$ bar. Dose was prepared by dilution of dried residues obtained from rotavator in $5 \%$ ethanol. The routes of dose administration of herbal as well as arsenicals to mice were oral.

\section{Slide preparation and observation}

Peripheral blood was collected for data evaluation from each mice of every cage by minor puncture on their tail. About 8-10 $\mu 1$ of blood collected from each animal and immediately mixed with 3\% EDTA (Sigma, CAS 6381-92-6) to prevent their clotting. Blood was smeared on clean, surface sterilized micro glass slide (Blue star industries) of dimension $75 \mathrm{~mm} \times 25 \mathrm{~mm} \times 1.35 \mathrm{~mm}$ with variation in thickness $\pm 0.1 \mathrm{~mm}$. The erythrocytes were fixed in $100 \%$ methanol for one minute and slides were incubated for 8 hours at $42^{\circ} \mathrm{C}$. The fixed erythrocytes were stained with Harris hematoxylin mixed with $3 \%$ glacial acetic acid (Merck, CAS 64-19-7) for 10 minutes. Glacial acetic acid improves the specificity of chromatin material. Slides were then stained with 1/9 diluted Giemsa stain for 10 minutes. Three slides were made for each sample and number of micronuclei scored by two different observers to minimize error. Around 2000 cells were examined per slide to score micronuclei with light microscope (Olympus) under 10×100 (oil immersion) magnification .In each observation five fields were focused and each field contain approx 350-450 cells. The micronuclei have similar color intensity to the main intact nucleus and area less than $1 / 3$ of main nucleus was only considered during scoring. Keen analyses were done to evaluate the effect of arsenicals as well as effects of stem extract of test plant on arsenical pretreated animals. The results were expressed in the terms of mean, standard deviation, variance and data were statistically analyzed.

\section{Result And Discussion}

The present study showed that the mean body weight of mice were decreased on administration of sodium arsenite (as shown in table 01), while there is increase in weight after administration of ethanolic extract of $T$. cordifolia in sodium arsenite pretreated groups.

Table: 01 Body weight $(\mathrm{gm})$ of treated mice (mean $\pm \mathrm{SD})$.

\begin{tabular}{|l|l|l|l|}
\hline Group & Dose level & Mean \pm SD & Variance \\
\hline $\mathbf{0 1}$ (Control) & $00 \mathrm{mg} / \mathrm{kg} \mathrm{(Tap} \mathrm{water)}$ & $29.36 \pm 3.001$ & 9.006 \\
\hline $\mathbf{0 2}$ & $\begin{array}{l}4 \mathrm{mg} / \mathrm{kg} / \mathrm{body} \mathrm{weight} \mathrm{sodium} \\
\text { arsenite }\end{array}$ & $28.98 \pm 2.017$ & 4.068 \\
\hline $\mathbf{0 3}$ & $\begin{array}{l}\mathrm{mg} / \mathrm{kg} / \mathrm{body} \text { weight sodium } \\
\text { arsenite }\end{array}$ & $26.68 \pm 2.233$ & 4.986 \\
\hline
\end{tabular}




\begin{tabular}{|l|l|l|l|}
\hline $\begin{array}{l}\mathbf{0 4}(4 \mathrm{mg} / \mathrm{kg} / \mathrm{bodyweight} \\
\text { sodium arsenite pretreated) }\end{array}$ & $\begin{array}{l}80 \mathrm{mg} / \mathrm{kg} / \text { body weight } \\
T . \text { cordifolia } \text { extract }\end{array}$ & $31.91 \pm 2.735$ & 7.480 \\
\hline $\begin{array}{l}\mathbf{0 5}(4 \mathrm{mg} / \mathrm{kg} / \mathrm{bodyweight} \\
\text { sodium arsenite pretreated) }\end{array}$ & $\begin{array}{l}80 \mathrm{mg} / \mathrm{kg} / \text { body weight } \\
T . \text { cordifolia } \text { extract }\end{array}$ & $32.01 \pm 2.748$ & 7.551 \\
\hline
\end{tabular}

Arsenic significantly induces the formation of micronuclei due to its clastogenic properties but frequency of micronuclei were drastically decreased in the $T$. cordifolia herbal treated groups because ethanolic extracts of test plant causes reduction of micronucleus formation to a great extent. Thus ethanolic extract of Tinospora cordifolia may have good anticlastogenic effect on arsenic induced genotoxicity. The percentage frequencies of micronuclei were expressed in the terms of mean and standard deviation which illustrates antimutagenic or anticlastogenic property of $T$. cordifolia (table 02 ).

Table: 02.Mean and standard deviation of micronucleus frequency in mice peripheral blood.

\begin{tabular}{|l|l|l|}
\hline Group & $\begin{array}{l}\text { \% frequency of MN } \\
\text { (Mean } \pm \text { SD) }\end{array}$ & Variance \\
\hline 01 (control) & $0.1002 \pm 0.08877$ & 0.0078 \\
\hline 02 (sodium arsenite treated) & $0.8438 \pm 0.3318$ & 0.1100 \\
\hline 03 (sodium arsenite treated) & $0.8625 \pm 0.3198$ & 0.1022 \\
\hline $\begin{array}{l}04 \text { (T. cordifolia stem extract } \\
\text { treated) }\end{array}$ & $0.1250 \pm 0.0288$ & 0.0008 \\
\hline $\begin{array}{l}05 \text { (T. cordifolia stem extract } \\
\text { treated }\end{array}$ & $0.1248 \pm 0.0278$ & 0.0007 \\
\hline
\end{tabular}
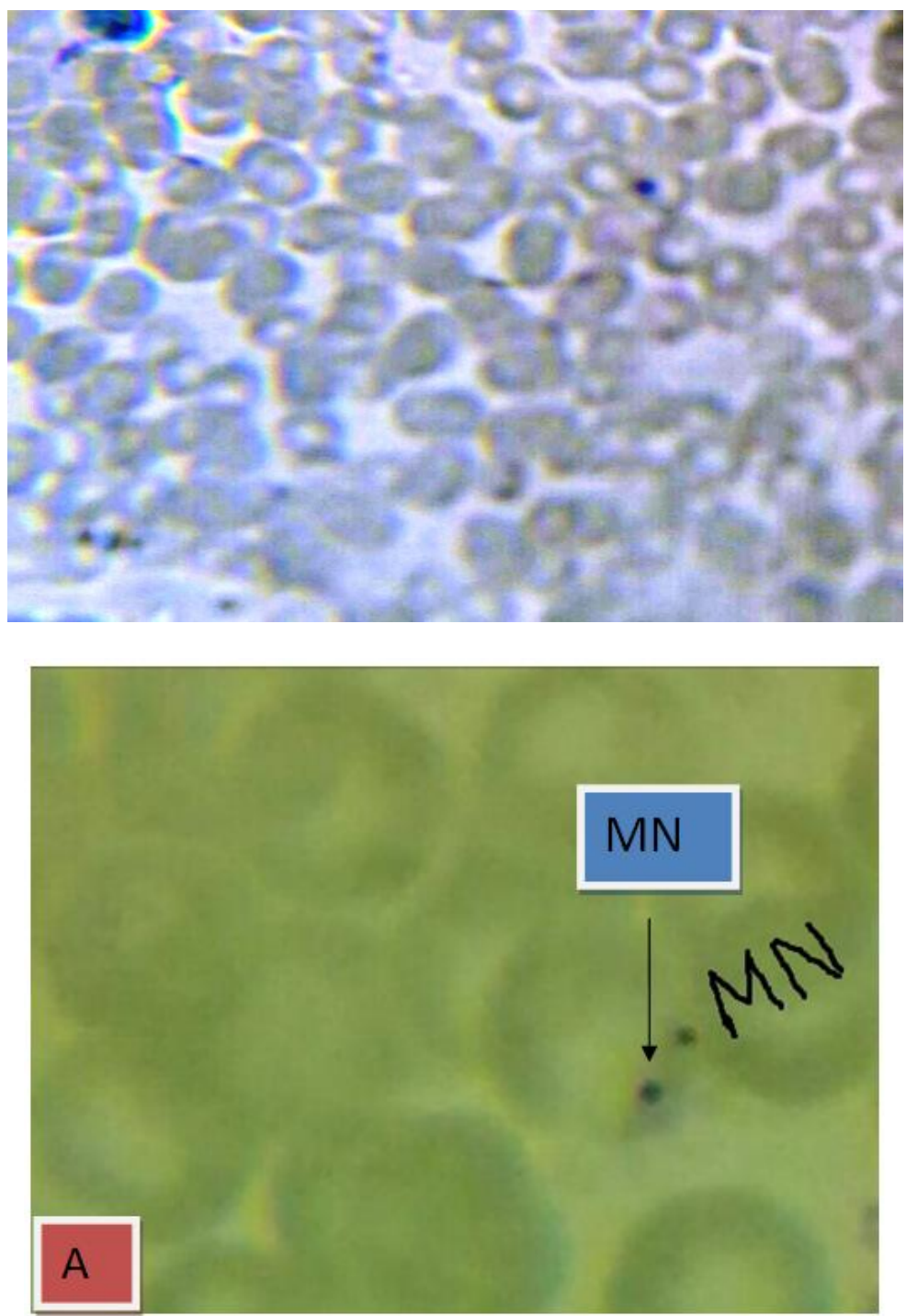

Figure: 01.Microphotograph (A--B) showing micronuclei in peripheral erythrocyte at magnification $(10 \times 100)$ under oil immersion. 


\section{Conclusion}

Tinospora cordifolia stem extract has minimizing effect on the clastogenicity due to arsenic toxicity. Antimutagenic property of such test plant may be proven as potent herbal drug for curing of disorders associated with genotoxicity. These results were noteworthy with respect to preventive aspects of diet and water in chemical carcinogenesis due to arsenic which leads to different types of degenerative diseases. So these herbal extracts are used as effective drug in preventive cancer against arsenic induced genotoxicity.

\section{Acknowledgment}

This present study was financially supported by Ministry of Science and Technology (Government of India) under project named as DBT-PU-IPLS, Sanction No: BT/PR4577/INF/22/149/2012. We were also thankful to Mahavir Cancer Research Institute, Patna, India for technical supports.

\section{References}

[1]. F. K. Ali, A.M. EL-Shehawi, M . A Seehy, Micronucleus test in fish genome: A sensitive monitor for aquatic pollution. African journal of biotechnology, 7, 2008, 606-612.

[2]. S. Kousar, M. Javed, Studies on induction of nuclear abnormalities in peripheral blood erythrocytes on fish exposed to copper. Turkish journal of fisheries and aquatic science, 15, 2015, 879-886.

[3]. A.M.A. AL-Amery, Evaluate micronuclei in the peripheral blood lymphocyte of sarcocystosis infected Ewes. International journal of research and development in pharmacy and life sciences, 5, 2016, 1929-1933.

[4]. N. Holland, C. Bolognesi, S. Bonassi, E. Zeiger, M. Fenech, The micronucleus assay in human buccal cells as a tool for biomonitoring DNA damage: The HUMN project prospective on current status and knowledge gap. Mutation research, 659, 2008, 93-108.

[5]. K. Zelazna, K. Rudnicka, S. Tejs, In vitro micronucleus test assessment of polycyclic aromatic compound. Environmental biology, 7, 2011, 70-80.

[6]. D. Endoh, N. Hashmoto, F. Sato, M. Kuwabara, Micronucleus test in mice fed on irradiated diet. Japanese journal of veterinary research, 37, 1989, 41-47.

[7]. S. Sharma, G. K Sharma, A. Mehta, Antimutagenic protection of Ficus benghalensis extract against cyclophosphamide induced genotoxicity in rat bone marrow. Asian journal of Pharmaceuticals and clinical research, 5, 2012, 84-86.

[8]. X. C. Abrevaya, M. A Carballo, Md. Mudry, The bone marrow micronucleus test and metronidazole genotoxicity in different strains of mice. Genetics and molecular biology, 30, 2007, 1139-1143.

[9]. X. Xhou, G. F. Loarca, G. G. Arreola, S. U. Lecona, Mouse- erythrocyte micronucleus (Mus-EMN) assay on the clastogenicity of industrial wastewater. Rev. Int. Contam. Ambient, 11, 1995, 95-98.

[10]. M. K. Ahmed, M. A. Hossain, M. Arif, E. Perwin, Ms. Akter, M. S. Khan, M. M. Islam, Assessing the genotoxic potential of arsenic in Tilapia using alkaline comet assay and micronucleus test. Chemosphere, 84, 2011, 143-149.

[11]. B. Unni, S. Das, M. Bhattacharjee, S. B Wann, P. G Rao, Toxicological effects of arsenic exposure in a fresh water teleots fish, Channa punctatus. African journal of biotechnology, 11, 2012, 4447- 4457.

[12]. A. Szymanska-Chabowska, J. Antonowicz- Juchniewicz, R. Andrzejak, some aspect of arsenic toxicity and Carcinogenicity in living organism with special regards to its influence on cardiovascular system, blooid and bone marrow. International journal of occupational medicine and environmental health, 15, 2002, 101-116.

[13]. M.G. Andreassi, F. Faita, L. Cori, F. Bianchi, Arsenic induced genotoxicity and genetic susceptibility to arsenic related pathologies. Int. J. Environment Res. Public Health, 10, 2013, 1527-1546.

[14]. V. Sharma, R. C Agrawal, Evaluation of anticlastogenic effects of Glycyrrhiza glabra root extract against cyclophosphamide induced chromosomal aberration in Swiss albino mice. Journal of applied pharmaceutical sciences, 5, 2015, 127-132.

[15]. R. Verma, H. S. Chaudhary, R. C. Agrawal, Evaluation of anticarcinogenic and antimutagenic effect of Tinospora cordifolia in experimental animals. Journal of chemical pharmaceutical research, 3, 2011, 877-881.

[16]. M. Pandey, S. K. Chikara, M. K. Vyas, R. Sharma, G. S. Thakur, P. S. Bisen, Tinospora cordifolia: A climbing shrub in health care management. International journal of pharmaceutical and biosciences , 3, 2012, 612-618.

[17]. F. Aqil, I. Ahmed, Z. Mehmood, Antioxidant and free radical scavenging properties of twelve traditionally used Indian medicinal plants. Turk J Biol , 30, 2006, 177-183. 